\title{
COMMUNICATIONS
}

\section{REFLECTIONS ON THE STRUCTURE OF THE WORD SVETOTATSTVO}

BORIS PARASHKeVOV

SOFIA UNIVERSITY ST. KLIMENT OHRIDSKI

boris_par@male.bg

The article discusses the noun светотатство ('sacrilege') in Bulgarian and Russian, which is derived from the obsolete word mam ('thief, robber'). The structure of the derivative suggests that it should be a loan translation of the Latin sacrilegium or the se-

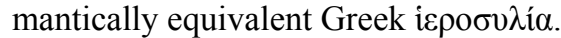

Keywords: Old Bulgarian, archaisms, etymologization, loan translation

\section{REFERENCES}

БЕР 2002: Български етимологичен речник. Том VI (пускам - словар2). Анастасов, В. и др. София. Академично издателство „Проф. Марин Дринов“. [BER 2002: Balgarski etimologichen rechnik. Tom VI (пускам - словар2) Anastasov, V. et al. Sofia. Akademichno izdatelstvo „Prof. Marin Drinov“.]

БЕР 2010: Български етимологичен речник. Том VII (слово - терясвам). Отг. ред. Т. Тодоров. София. Академично издателство „Проф. Марин Дринов“. [BER 2010: Balgarski etimologichen rechnik. Otg. red. T. Todorov. Sofia. Akademichno izdatelstvo „Prof. Marin Drinov“.]

БНК: Българския национален корпус. $<$ http://search.dcl.bas.bg/>. [BNK: Balgarski nacionalen korpus. $<$ http://search.dcl.bas.bg/>.]

Богоров 1869: Богоров, Ив. Френско-български речник. Дял пьрви. Виена. Книгопечатница Л. Соммерова и др. [Bogorov 1869: Bogorov, Iv. Frenskobalgarski rechnik. Dyal parvi. Viena. Knigopechatnitsa L. Sommerova i dr.]

Богоров 1871: Богоров, Ив. Българско-френски речник. Дял втори. Виена. Книгопечатница Л. Соммерова и др. [Bogorov 1869: Bogorov, Iv. Balgarskofrenski rechnik. Dyal vtori. Viena. Knigopechatnitsa L. Sommerova i dr.]

Гегова 2019: Гегова, Ил. Социолингвистични аспекти на банатския говор. Дисертация за присъждане на образователната и научна степен „доктор“. София. Манускрипт. [Gegova 2019: Gegova, Il. Sotsiolingvistichni aspekti na banatskiya govor. Disertatsiya za prisazhdane na obrazovatelnata i nauchna stepen ,doktor“. Sofia. Manuskript.]

Геров 1978: Геров, Н. Речник на българския език. Фототипно издание. Част пета и Допълнения. София. Издателство „Български писател“. [Gerov 1978: Gerov, N. Rechnik na balgarskiya ezik. Fototipno izdanie. Chast peta i Dopalneniya. Sofia. Izdatelstvo „Balgarski pisatel“.] 
Марков 1906: Марков, Н. Пълен френско-български речник. Второ издание, илюстровано. София. Издание „Глобус“. [Markov 1906: Markov, N. Palen frensko-balgarski rechnik. Vtoro izdanie ilyustrovano. Sofa. Izdanie „Globus“.]

Младенов 1941: Младенов, $\mathrm{Cm}$. Етимологически и правописен речник на българския книжовен език. София. Книгоиздателство Христо Г. Данов - О. О. Д-во. [Mladenov 1941: Mladenov, St. Etimologicheski i pravopisen rechnik na balgarskiya knizhoven ezik. Sofia. Knigoizdatelstvo Hristo G. Danov.]

ОПРБЕ 2012: Официален правописен речник на българския език. Авторски колектив. ИБЕ „Проф. Любомир Андрейчин“. София. Издателство „Просвета“. [OPRBE 2012: Ofitsialen pravopisen rechnik na balgarskiya ezik. Avtorski kolektiv. IBE „Prof. Lyubomir Andreychin“. Sofia. Izdatelstvo „Prosveta".]

РБЕ: Речник на българския език (онлайн). ibl.bas.bg/rbe/lang/bg. [RBE: Rechnik na balgarskiya ezik (on line). <ibl.bas.bg/rbe/lang/bg >.]

РРОДД 1974: Илчев, Ст. и др. Речник на редки, остарели и диалектни думи от XIX и XX век. София. Издателство на БАН. [RRODD 1974: Ilchev, St. et al. Rechnik na redki, ostareli i dialektni dumi ot XIX i XX vek. Sofia. Izdatelstvo na BAN.]

ССРЛЯ 1962: Словарь современного русского литературного языка. Т. 13. Москва - Ленинград. Издательство академии наук CCCP. [SSRLI 1962: Slovar' sovremennogo russkogo literaturnogo iazyka. T. 13. Moskva - Leningrad. Izdatel'stvo akademii nauk SSSR.]

Vasmer 1958: Vasmer M. Russisches etymologisches Wörterbuch. Bd. III. Heidelberg. Carl Winter Universitätsverlag.

$\triangle$ Prof. Boris Parashkevov, PhD Department for German and Scandinavian Studies Faculty of Classical and Modern Philology Sofia University „St. Kliment Ohridski“ 15 Tsar Osvoboditel Blvd, 1504 Sofia, Bulgaria 